\title{
More than noise? Explaining instances of minority preference in correspondence studies of recruitment
}

\author{
Giuliano Bonoli ${ }^{\text {a) }}$ and Flavia Fossati ${ }^{\text {b) }}$
}

Published in Journal of Ethnic and Migration Studies on July 26, 2018

\begin{abstract}
Correspondence studies of labour market discrimination find that minorities, which in general suffer disadvantage, are sometimes preferred in a choice against members of the majority. This outcome has been observed in several studies of ethnic or nationality-based discrimination, but also in studies focusing on other characteristics, such as unemployment and being overweight. However, it is generally not explained and dismissed as noise. In this paper we challenge this understanding, and, using metaanalytical techniques, we show that instances of minority preference are not randomly distributed. We also show that they are more frequent for groups which overall suffer stronger discrimination and for high skilled professionals. We reason that this result may be explained with the fact that groups that suffer discrimination have fewer alternatives in the labour market and this makes them more attractive for jobs of sub-standard quality and for jobs in which turnover costs are high (e.g. high skilled professionals). We conclude by arguing that since tests in which the minority candidate is preferred are not randomly distributed, future research should study the determinants of minority preference in a more systematic manner.
\end{abstract}

\section{Acknowledgments}

We thank Dorian Koller for excellent research assistance, Damaris Rose and Fabienne Liechti for comments. This research was conducted within the framework of the nccr-on the move (project 7), which is financed by the Swiss National Science Foundation.

Keywords: correspondence testing; discrimination; minority; hiring; employers

\section{Contacts}

a) Giuliano Bonoli, University of Lausanne, Bâtiment IDHEAP, Rue de la Mouline 28, 1015 Lausanne, Email: giuliano.bonoli@unil.ch.

b) Flavia Fossati, University of Lausanne, Bâtiment IDHEAP, Rue de la Mouline 28, 1015 Lausanne, Email: flavia.fossati@unil.ch, ORCID ID: 0000-0002-9218-5422.

\section{Biographical notes}

Giuliano Bonoli is Professor of social policy at the Swiss graduate school for public administration at the University of Lausanne. His work has focused on pension reform, labour market and family polices, with particular attention paid to the politics of welfare state transformation. He has published some fifty articles and chapters in edited books, as well as a few books. He is the author of "The origins of active social policy. Active labour market policy and childcare in a comparative perspective", (Oxford University Press, 2013).

Flavia Fossati is a postdoctoral researcher at the University of Lausanne. Her research interests include labour market, education and migration policy, hiring discrimination, comparative politics and welfare 
state research. Her work has been published among others in Socio-Economic Review, International Migration Review and European Sociological Review.

\section{1) Introduction}

Studies on labour market discrimination sometimes produce puzzling results. In some instances, applicants who belong to groups that are generally discriminated against are preferred to candidates who are not expected to face discrimination. This applies to many studies on ethnic discrimination, which find that sometimes, in individual tests of pairs of applications, an employer may prefer the ethnic minority applicant to the majority candidate. More rarely, but in the context of an overall very small number of studies, this phenomenon has been observed also in relation to other factors known to elicit discrimination, such as long-term unemployment or physical appearance. In general, all these studies dismiss this counterintuitive finding as 'noise', or as a random component in hiring decisions. We believe that it can be explained.

Theoretically, there are reasons to prefer a candidate who belongs to a group that is known to be discriminated against in the overall labour market. In fact, such candidates have fewer alternatives, thus, all else equal, these candidates can be expected to be more loyal, more tractable, and possibly more productive at any given wage level, as will be shown in the theory section below. As a result, in some instances, employers may rationally prefer a candidate belonging to a group that is discriminated against to one who is not. In the following discussion, for the sake of simplicity, we refer to candidates belonging to groups that are discriminated against as 'minority candidates' and to those belonging to groups who are not discriminated against as 'majority candidates'. In the context of correspondence studies, minority preference refers to those (rare) instances in which a minority candidate is preferred over a majority candidate.

We hypothesise that individual instances of minority preference will be more prevalent in two segments of the labour market. First, we expect employers to prefer minority candidates when hiring for particularly unattractive positions, which tend to be avoided by those who have alternatives. These can be low quality, low status, and low paid jobs. Second, we expect employers to prefer minority candidates for positions for which turnover costs are high. These could be mid- to high-skilled positions which require a big investment on the employer`s side, for instance in terms of in-firm training (e.g. managers, 
IT-professionals, and accountants), or jobs in sectors where there is labour shortage and for which firms have difficulties finding suitable applicants. In these cases, hiring a minority candidate could be associated with a lower turnover risk. In both instances, what makes a minority candidate attractive is the fact that, relative to majority candidates, they (are expected to) have fewer alternatives in the labour market.

In this paper, we first consider the mechanisms that can explain the preference given to a minority against a majority candidate on a theoretical level. To do this, we rely on both qualitative and quantitative literature on labour market discrimination and human resources management studies, and particularly on the literature about the determinants of turnover intentions. In the empirical section, using metaanalytical techniques, we attempt to identify patterns in the occurrence of instances of minority preference. For our meta-analysis we use a corpus of $15^{1}$ studies on ethnic discrimination in the labour market that provide information on the three different outcomes: only the majority candidate, only the minority candidate, or both are invited. Within this corpus we were able to identify 139 usable estimates of discrimination (an estimate concerns a group of individual tests performed for a given occupation). We found instances of minority preference in 96 of the 139 estimates (or 69\%). The proportion of individual tests in which the minority candidate is the only one to be invited ranges from $0 \%$ to $42 \%$, with an average of $8 \%$.

\section{2) Explaining employers` preferences for hiring minority workers}

How do we explain individual instances of minority preference in correspondence studies? In the literature, they are generally considered to be noise. Most studies calculate a net discrimination rate, whereby the number of tests in which only the minority candidate is invited is subtracted from the number of tests in which only the majority candidate is invited. As a result, the information concerning

\footnotetext{
${ }^{1}$ The curvilinear relationship could be replicated also with a bigger sample of 29 studies that consider a total of 249 estimates of disadvantage (see Figure S1 in the supplementary material). However, in these 14 additional studies, besides different occupations job related characteristics such as skill level, firm size, sector of occupation, are included as well.
} 
the instances of minority preference is lost. In other words, what is usually considered is only the difference between majority and minority preference. Thus, very different combinations of call-back rates can produce exactly the same net discrimination rate. For example, a net discrimination rate of 0 can be obtained when both candidates are invited in all tests but also when only the majority candidate is invited in $50 \%$ of the test and only the minority candidate is invited in the remaining $50 \%$ of the tests. This is obviously an extreme case, but it illustrates that focusing on net discrimination only may be misleading ${ }^{2}$.

As noted by Heckman and Siegelman (1993: 198), this implies that 'the proportion of trials in which blacks [minority] are hired and whites [majority] are not, constitutes a benchmark measure for “randomness" in employment decisions'. This 'randomness' can have different causes, such as a mistake by the experimenter, the application from the majority candidate is lost or arrives when the employer has already identified enough candidates.

In contrast, we believe that there are powerful theoretical reasons why an employer may intentionally prefer a minority candidate to a majority candidate. What makes the minority candidate attractive is precisely the fact that he or she is discriminated against and, if hired, will have fewer alternatives than a majority candidate. This quality is likely to be relevant in contexts in which hiring is potentially difficult. More specifically, we can identify two situations in which we expect minority preference to be more widespread: low desirability jobs avoid; and jobs where employers face high turnover costs.

\section{1) Recruiting for undesirable jobs}

A vast literature has shown that employers target disadvantaged workers for undesirable jobs (Faist 1994: 445; Tilly and Moss, 2001: 153; Shih, 2002; Waldinger and Lichter, 2003; Pager et al 2009; Hasluck, 2011; Friberg, 2012: 1924). At the macro level, research on labour market segmentation has

\footnotetext{
${ }^{2}$ The net discrimination rate is only one of the different methods used to report findings of correspondence tests. However, this problem applies to all methods that are usually applied, such as call back rates by ethnicity or odds ratios. In either case, the information on the proportion of individual paired tests in which only the minority candidate is invited is lost and thus remains unexplained in the quantitative literature.
} 
pointed out that disadvantaged groups, defined most often in terms of ethnicity, tend to get trapped in lower labour market segments. This phenomenon has first been theorised by US scholars in the 1970s (see e.g. Reich, Gordon and Edwards 1973; Piore 1979). They argued that ethnic minority workers were overrepresented in a secondary or lower labour market segment because employers could not rely on native workers to fill vacancies for undesirable jobs. Piore (1979: 15) talks of 'occupations rejected by indigenous workers (...) typically such jobs offer low pay, poor working conditions, little security and inferior social status'. These arguments have found confirmation in micro-level studies- Employers recruiting for badly paid jobs have sometimes been found to prefer minority candidates. Moss and Tilly (2001: 153) report that ' $(\ldots)$ at business where managers praised Latinos, Asians, immigrants or African Americans, average wages fell markedly below the sample's overall average'. Pager et al. (2009: 790791) found that on occasions minority applicants were offered lower paying and lower skilled jobs than the one they had applied for.

Reasons given for preferring minority workers are generally related to the fact that they have fewer alternatives in the labour market than natives. Among other things, these results in higher levels of tractability, i.e., the fact of being more inclined to uncritically accept management's requests. Studies of low skill employment have shown that tractability (often expressed in terms of 'motivation') is a highly sought-after quality in the low skill segment of the labour market (Moss and Tilly 2001, Zamudio and Lichter 2008; Bonoli and Hinrichs 2012, Friberg 2012, Raikes and Davies 2015).

Ethnicity-based preferences for candidates are complex, and are often structured as hierarchies (Haagendorn 1993; 1995). The rank ordering of ethnic groups, however, can vary depending on the labour market segment. In a Swiss study on recruitment in the hotel sector, Auer et al (2018) found that positions at different skill levels generated different nationality-based rankings in employers' preferences. For mid-skilled positions (i.e. receptionists), Swiss candidates were very clearly preferred to foreigners. For low skilled positions (room cleaner) instead, foreigners were ranked similarly to Swiss.

This preference for immigrants sometimes translates into ethnic niches in specific industries. This is the case for example in the fishing industry in Norway, where employers actively recruit eastern European 
rather than Norwegian workers, because these are more likely to accept the harsh conditions that characterise this profession. Interestingly, more recently arrived immigrants are found to be preferred to those who came in the past, at least if they stem from the European Union (Friberg and Midtbøen 2018). Based on this evidence, we hypotheses that preferences towards specific groups of minority workers should correlate with the level of discrimination they face.

The idea that employers may intentionally prefer a minority over a majority candidate is often found in the qualitative literature on ethnic-based labour market discrimination. However, very few attempts have been made to test this idea in a quantitative study (Auer et al. 2018 is an exception). We argue that these candidates are preferred because they suffer discrimination and thus are less likely to change job once they found a position.

\section{2) Minimising turnover intentions}

Besides having to recruit for low desirability jobs, there are other reasons to prefer a candidate who, if hired, would have few employment alternatives. Firms have difficulties recruiting and keeping skilled staff in many specialised occupations. In this case, recruiting candidates with a migration background may be a strategy to minimise turnover intentions.

The literature on human resources management has analysed the process of deciding to quit one's employer. One of the most widely used models was developed Meyer and Allen (1991: 71) and argues that various factors impact on the decision to leave a firm, including affective and normative factors. One important element in the decision is the value of the perceived employment alternatives, which is part of what they call 'continuance commitment'. ${ }^{3}$ In empirical studies, perceived employment alternatives are generally measured with survey items eliciting an opinion on how easy it would be for a respondent to find employment of equal or better quality. These items tend to be positively correlated

\footnotetext{
3 'Continuance commitment' refers to a rational calculus of the costs associated with quitting a job. It depends essentially on investments and alternatives (Meyer and Allen 1991: 71)
} 
to turnover intentions and, in longitudinal studies, to a higher probability of quitting at a subsequent time (Rusbult and Farrel 1983; Vandenberghe 2015). The relevance of perceived employment alternatives as a determinant of turnover intentions and decisions has also been confirmed in meta-analyses. A better assessment of one's alternatives is associated with a stronger inclination to quit, even though the strength of the effect varies (Griffeth et al 2000; Meyer et al. 2002; Jiang et al. 2012).

We make the plausible assumption that the perception of fewer employment alternatives is associated with a lower likelihood to quit an employer. However, this assumption is not sufficient. We also need to assume that being exposed to discrimination reduces perceived employment alternatives. Unfortunately, the question of what are the determinants of perceived employment alternatives has not received much attention in the human resources literature, and we were not able to find studies focusing specifically on this question. However, for our argument, it is essential to know what the determinants of perceived employment alternatives are and if the fact of being exposed to labour market discrimination is among them. To do this we use questions on perceived employment alternatives that are available in the European Social Survey (ESS) round 5 for the year $2010 .{ }^{4}$ By means of multivariate analyses we identify a relatively strong negative correlation between a subjective feeling of being discriminated against and perceived employment alternatives. ${ }^{5}$ The correlation is robust and holds when using a range of controls that impact on perceived employment alternatives (such as age, level of education, nationality; details on the operationalisation and the models are shown in appendix Tables A1 and A2). Thus, our assumption that individuals who suffer discrimination believe that they have fewer alternatives than those who do not, is not only theoretically plausible, but is confirmed by this empirical evidence.

\footnotetext{
${ }^{4}$ The same analyses were replicated for round 2 for the year 2004 and yield similar results.

${ }^{5}$ Perceived employment alternatives were measured by the question 'How difficult or easy would it be for you to get a similar or better job with another employer if you had to leave your current job'. Subjective discrimination with the question: 'Would you describe yourself as being a member of a group that is discriminated against in this country?'
} 


\section{3) Lack of alternatives as a positive feature}

The lack of alternatives may make candidates attractive because they are more likely to accept undesirable working conditions and less likely to quit. In addition, 'efficiency wage' theory suggests that candidates with fewer alternatives are likely to be more productive at any given wage level. This expectation is based on the observation that labour contracts are imperfect, and employees have some discretion regarding their level of commitment. They can be highly motivated or can withhold effort (i.e., shirk) (Offe and Hinrichs 1985). To limit this phenomenon, employers can decide to pay wages that are higher than market clearing ones (so-called efficiency wages), so that if caught shirking and dismissed, an employee will be left with a wage loss, even under full employment (Shapiro and Stiglitz 1984). For discriminated workers, however, there is no need to pay wages above market level because they have few alternatives to their present job. If caught shirking and dismissed, they face the risk of prolonged unemployment. The consequence is that with for minority workers the efficiency wage is likely to be below the market clearing rate, which makes them attractive for employers. ${ }^{6}$

Our theoretical model of minority preference requires some further specifications. First, it should be made clear that only candidates who lack alternatives due to reasons that are unrelated to their productivity, like discrimination, are expected to be attractive for employers. Instead, for candidates who lack alternatives because they are not productive the mechanisms we discuss here is irrelevant. Second, we do not expect all employers to prefer minority candidates. If this were the case, discrimination would be a time-limited phenomenon for any given group. As employers recognise the attractiveness of candidates who have few alternatives, they would start to prefer them, and discrimination should decline/disappear. In reality, this does not happen. As recently shown in relation to African-Americans in the US, labour market discrimination can be a very persistent trend (Quillian et al 2017).

Labour market discrimination is arguably a very complex phenomenon, driven by rational considerations based on statistical reasoning but also by psychological mechanisms such as stereotypes

\footnotetext{
${ }^{6}$ This hypothesis was suggested to us by Tobias Müller.
} 
and prejudice (Darity and Mason 1998). Our model considers only the first mechanism. The fact that not all employers behave as predicted by statistical discrimination theory can be explained with reference to other factors that contribute to the persistence of discrimination, like taste-based discrimination. Moreover, not all employers may be interested in hiring workers with few alternatives. For example, firms who can offer attractive working conditions may be less in need of this strategy. Finally, even within a statistical discrimination framework, employers who recognise the advantage of hiring workers who are unlikely to leave may still avoid minority candidates if they believe that the negative features associated with minority status (e.g. low productivity) outweigh this advantage.

Finally, we would like to stress that the mechanism that we want to study has been observed mostly in relation to discrimination based on ethnicity. There are however a few studies on other forms of discrimination whose results that are entirely compatible with this understanding of the way recruitment works. With respect to obesity, Rooth (2012) finds that obese candidates are generally discriminated against. All else equal, an obese-looking candidate has a lower chance to be invited for a job interview. For women, the difference between obese and normal weight candidates equals 8 percentage points. Intriguingly, in the case of nurses the opposite happened. For both men and women, there were more instances in which the obese-looking candidate was invited than cases in which the normal weight applicant was called back. Hiring an obese nurse may be advantageous for an employer because the supply is scarce and employers may want to ensure reducing turnover risk. Oberholzer-Gee (2006: 35) surveyed employers and found that given the choice between an employed and an unemployed candidate (for 12 months) 16.8 of his sample of 766 employers prefer the unemployed candidate (against 10.3\% for the employed candidate).

To sum up, we can say that there are both theoretical reasons and scattered empirical evidence suggesting that one or several mechanisms might be at play whereby candidates who are discriminated against become more attractive for some employers. Following from this observation, we can then formulate the hypothesis that minority preference will be positively correlated to gross discrimination. In other words, the more a group is discriminated against, the more likely we are to find instances of minority preference, i.e. situations in which only the minority candidate is called back. 
Next, we subject this hypothesis to a more systematic test based on meta-analytical techniques.

\section{3) Methodology}

In order to test our hypothesis, we rely on results from the empirical literature on discrimination, and particularly on correspondence testing. Correspondence testing is the standard method used to study discrimination in the labour market. In the typical set up, fictitious pairs of CVs are sent to real job openings. The CVs are identical (or equivalent) in every respect except in the feature that is suspected to be responsible for discrimination. The researchers then observe who is invited for a job interview. Most studies present the results in terms of call back rates for the different subgroups (for an overview see Riach and Rich, 2002; Rich, 2014; Bertrand and Duflo, 2017; Zschrint and Ruedin, 2016; Quillian et al 2017).

As mentioned above, the number of individual tests in which only the minority candidate is invited are typically subtracted from those in which the majority applicant is the only one getting a call-back. This procedure de facto considers instances of minority preference as noise or, as Heckman and Siegelman (1993) put is an element of 'randomness' in employment decisions.

If this view is correct, then instances of minority preference should be randomly distributed across studies using the correspondence test method. If, however, the mechanism we hypotheses exists, there should be a positive correlation between the gross discrimination rate (i.e. the proportion of tests in which only the majority candidate is called back) and the minority preference rate (i.e. the proportion of tests in which only the minority candidate is called back). Remember that our hypothesis implies that the more a group is discriminated against, the more it becomes attractive for employers preferring employees who have few alternatives.

We expect the relationship between gross discrimination and minority preference to be positive but not linear. In fact, since we are working with rates (percentages), there is a ceiling effect. Basically, the sum of the gross discrimination rate, the minority preference rate and the equal treatment rate cannot exceed 100. As a result, we expect the relationship to have a quadratic rather than a linear shape. Figure 1 shows what we expect to find if our hypothesis is correct. Profiles that are not discriminated against are also 
rarely preferred for jobs in which having few alternatives is an advantage. Then, as gross discrimination increases (majority preferred) minority preference also increases, up to a point. When both rates are high, the ceiling effect kicks in and the relationship flattens or turns negative.

\section{$>$ Figure 1<}

Our unit of analysis are estimates of discrimination, which are used in correspondence studies. Typically, correspondence studies provide overall results, and then breakdowns by job type, economic sector or nationality of the applicant. Our unit of analysis is the result for these different sub-groups within studies. We decided to use estimates of discrimination as unit of analysis (rather than whole studies) because the sort of effect we hypothesise may play out differently across labour market segments and ethnic groups. Studies are sometimes rather heterogeneous in both respects, and this may result in the putative effect to be diluted and invisible. Estimates of discrimination are sub-units of studies, and we take this into account by using multilevel modelling. Note that this is standard practice in meta-analyses of correspondence studies (see e.g. Zschirnt and Ruedin 2016; Quillian et al 2017).

\section{4) Data}

We constructed a dataset containing results of correspondence studies. For our analyses, we focus essentially on two variables: the gross discrimination rate and the minority preference rate. The former refers to the percentage of valid applications ${ }^{7}$ in which only the majority candidate is invited, the latter to the proportion in which only the minority candidate is called back.

\footnotetext{
${ }^{7}$ Valid applications equal the number of total callbacks, i.e where both, or either the majority or the minority candidate were invited for a job interview. Thus, the only cases that are excluded are the instances where neither candidate is called back.
} 


$$
\text { Gross discrimination }=\frac{\text { callback }_{\text {majority only }}}{\text { total callbacks }}
$$

$$
\text { Minority preference }=\frac{\text { callback }_{\text {minority only }}}{\text { total callbacks }}
$$

To build our dataset we relied on existing meta-analyses of discrimination in hiring using the studies by Riach and Rich (2002), Rich (2014), Zschirnt and Ruedin (2015), and Berntrand and Duflo (2017). We compiled a dataset that in a first step includes the results of all written correspondence testing ${ }^{8}$ that analyse the labour market access of ethnic or national minority candidates in different occupations, for different skill levels, in different regions, etc.. We include only studies that provide the information on raw call-back rates for both majority and minority applicants to be able to compare the results across the different studies in a meaningful way. In other words, we refrained from including papers that merely provide estimations or coefficients as these are difficult to compare. Overall, we retained 29 of 54 available studies ${ }^{9}$ (see table A1-A4 in the appendix for a complete list).

However, because the classifications in terms of job characteristics are very heterogeneous we re-run all the analyses also on a smaller subset of studies that distinguish among minority and majority candidates but for specific occupations (rather than one of the other characteristics e.g., skill levels, unemployment levels, geographical region). This further reduces the number of available studies to 15 and the number of discrimination estimates to 139. As the results for both samples are similar, we present the estimations of what we believe to be a more homogenous and thus appropriate sample to test our hypotheses ${ }^{10}$.

\footnotetext{
${ }^{8}$ We did not include audit studies working with telephone or in person applications, survey or other types of experiments. We also excluded studies that do not analyse labour market outcomes (i.e., housing market, etc.).

${ }^{9} \mathrm{We}$ also exclude the 15 additional studies working with other methods than written correspondence testing.

${ }^{10}$ The estimation based on the larger sample can be found in the supplementary material in Table S4 and Figure S1.
} 


\section{5) Results}

Figure 2 shows the relationship between the gross discrimination rate, i.e. the proportion of cases in which only the majority candidate gets a call back (gross discrimination), and the minority preference rate, i.e. the proportion of tests in which only the minority candidate gets a call back. As expected, the relationship is curvilinear. This finding is compatible with our understanding that groups that are discriminated against become more attractive for some employers, possibly exactly because they are discriminated against.

\section{$<$ Figure 2>}

The curve fit is statistically significant, as can be seen in Table 1, which presents the results of various multivariate models. Model 1 contains only the gross discrimination rate (simple and squared) as independent variables. Our understanding is that minority preference will be most prevalent in low desirability jobs and in occupations in which turnover costs are high. For this reason, in Models 2 and 3 we consider the impact of job characteristics on the minority preference rate. Model 2 includes an occupational prestige score as calculated by Hout et al. (2010) for the 2010 Census. We would expect minority preference to be higher in low prestige jobs. However, this variable turns out to be nonsignificant.

\section{<Table 1>}

In Model 3 we include dummy variables for the occupation on the basis of the ISCO classification ${ }^{11}$. Unfortunately, the information provided in the studies we reviewed does not allow using a more fine-

\footnotetext{
${ }^{11}$ See also Figure S2 in the supplementary material.
} 
grained classification than ISCO's major groups (one-digit ISCO-88 classification). However, in relation to our research question, the trend emerging from the data is rather clear. Minority preference occurs most frequently in high skill professions (managers and professionals), and less so in all other occupations. It is important to underline that this finding does not equate to saying that high skilled minority applicants are less discriminated against. Instead what we show is that they are more often preferred to their majority competitor. Lower discrimination against high skill individuals because they can produce documented qualifications (e.g. diplomas, work experience) is not a sufficient explanation for this finding, as it fails to account for why, in these instances, the majority candidate is not invited. This result is only partially in line with our expectations. We would have expected a U-shaped relationship between the skill level of a job and preference for minority candidates, which, according to our model should be strongest in low desirability (i.e., low skill) jobs and as in jobs with high turnover costs (i.e., high skilled occupations). Instead, we find a stronger likelihood of minority preference only among the high skilled.

\section{6) Discussion}

Our analysis shows that instances of minority preference are not randomly distributed across estimates of discrimination. Instead, their occurrence is related to the gross discrimination rate in a curvilinear way, as we hypothesised. The curvilinear relationship between gross discrimination and the minority preference rate is robust, as it remains statistically significant with different model specifications. We believe that this relationship reflects the fact that workers who are discriminated against have fewer alternatives on the job market and that this makes them attractive to some employers ${ }^{12}$. Our results

\footnotetext{
${ }^{12}$ As indicated by one anonymous reviewer, the curvilinear relationship could also be driven by an unobserved variable that impacts on the proportion of tests in which both candidates are invited. This variable could be for example the total number of applications received for an opening. When there are few candidates overall, employers will tend to invite everyone, whereas when there are many candidates, they might be more selective and let both discrimination and noise (which determines minority preference) play a bigger role, hence the positive correlation. Since we do not have information on the total number of applicants we cannot rule out this alternative explanation. However this view is incompatible with the finding that minority preference is more prevalent among high skilled professionals. In fact, it seems reasonable to assume that there are fewer candidates for high skill than for low skill jobs, so that if the effect we see were driven by varying numbers of applications, we should see less gross discrimination and less minority preference of high skilled vacancies, i.e. the opposite of what we see.
} 
suggest that this effect concerns mostly the high skilled segment of the labour market. This is somewhat surprising because in the qualitative literature a preference for minority candidates has been hypothesised and observed more frequently in relation to low skilled, undesirable jobs that majority candidates tend to avoid.

We should point out that this somewhat unexpected result may be due to a bias in the corpus of literature we used for the meta-analysis, where we find an overrepresentation of mid- to high- skilled occupations. This is arguably due to the fact that the method used in the studies we considered, i.e. correspondence testing, requires applications to be written. As we know, recruitment in the low skill segment of the labour market, instead, tends to be based on personal contacts and applications in person (Rebien 2010; Bonoli and Hinrichs 2012). This reduces the number of correspondence studies that focus on the low skill/low wage segment of the labour market ${ }^{13}$.

We explain the observed result in terms of a (rational) preference given to candidates who have few alternatives. But are there other explanations? Often in the field of discrimination research rational choice explanations compete with psychological accounts based on the notion of stereotype and prejudice (e.g., Fiske, 1998). According to this view, the preference sometimes given to ethnic minority candidates might reflect the stereotypes and images employers have constructed. Typically, for low skilled undesirable jobs, it is more common to imagine a migrant from a recently arrived group than a member of the majority. This alternative explanation could account for instances of minority preference in the low skill segment of the labour market. However, it is more difficult to produce a stereotypebased explanation for minority preference among higher skilled professionals, which, in our analysis, is the strongest effect.

Another alternative explanation could refer to affirmative action policies in recruiting. One could hypothesise that firms where ethnic minorities are underrepresented but committed to increasing staff

\footnotetext{
${ }^{13}$ We excluded audit studies because of the methodological problems linked to the difficulty of control for individual unobserved characteristics of the actors, who apply for the different positions, and in order to have a sample of estimates that is as homogenous as possible.
} 
diversity, might prefer minority candidates. Our data does not allow us to test this hypothesis, and we acknowledge that it could contribute explaining the observed pattern.

In sum, the curvilinear relationship between gross discrimination and minority preference that we have identified, in our view is best explained by the model we developed, which claims that the preference given to minority candidates is due to the fact that these have fewer alternatives in the labour market. These workers are more likely to be loyal and according to efficiency wage theory, more productive at any wage level.

\section{7) Conclusion}

The correspondence testing literature has consistently treated tests in which only the minority candidate is called back as a randomly distributed outcome that does not require explanation. We demonstrated that minority preference is related to gross discrimination and more frequent among high skilled professionals. This means that the assumption of random distribution regarding minority preference is inadequate.

What then, if not chance, explains the distribution of instances of minority preference? We argued that the preference sometimes given to minority candidates can be explained by employers' anticipation of them having fewer alternatives in the labour market. Our results are compatible with this account, however, the data we use does not allow us to test alternative hypothesis, such as for example the fact that companies who value diversity may intentionally prefer minority candidates if these are underrepresented or the fact that minority candidates are preferred because they conform to prevailing stereotypes.

The finding that minority preference is not distributed randomly, however, has implications for research on discrimination. If minority preference is driven by the fact that members of the minority have fewer alternatives and are, for example, more likely to accept low quality employment, then it is questionable to subtract minority preference from the gross discrimination rate. In a way, both results refer to 
(different) forms of discrimination. One leads to exclusion from the labour market, the other may lead

to entrapment in low quality employment.

The finding that minority preference is more prevalent among high skilled professionals is intriguing, and needs to be better understood. In general, we believe that our findings underscore the need for further research focusing on the determinants of minority preference, an outcome that has been almost entirely ignored in the quantitative literature so far.

\section{8) Literature}

Auer, D., Bonoli, G., Fossati, F., and Liechti, F. (2018, forthcoming). "The matching hierarchies model: Evidence from a survey experiment on employers." International migration review.

Bertrand, M., and Duflo, E. (2017). Field Experiments on Discrimination. In A. Banerjee and E. Duflo (eds.), Handbook of Economic Field Experiments, Vol. 1, pp. 309-393. Amsterdam: Elsevier.

Bonoli, G. and Hinrichs, K. (2012). "Statistical Discrimination and Employers' Recruitment." European Societies 14(3): 338-361.

Darity, W. A., and Mason, P. L. (1998). "Evidence on Discrimination in Employment: Codes of Color, Codes of Gender." Journal of Economic Perspectives 12(2): 63-90.

European Social Survey Round 2 Data (2004). Data file edition 3.5. NSD - Norwegian Centre for Research Data, Norway - Data Archive and distributor of ESS data for ESS ERIC.

European Social Survey Round 5 Data (2010). Data file edition 3.3. NSD - Norwegian Centre for Research Data, Norway - Data Archive and distributor of ESS data for ESS ERIC.

Faist, T. (1994). "States, Markets, and Immigrant Minorities: Second-Generation Turks in Germany and Mexican-Americans in the United States in the 1980s." Comparative Politics 26(4): 439-460.

Fiske, S. T. (1998). "Stereotyping, Prejudice, and Discrimination." In: Gilbert, D., Fiske S.T. and Lindzey, G. (eds.) The Handbook of Social Psychology. McGrew Hill, New York.

Friberg, J. H., and Midtbøen, A. H. (2017). "Ethnicity as skill: immigrant employment hierarchies in Norwegian low-wage labour markets." Journal of Ethnic and Migration Studies. doi: 10.1080/1369183X.2017.1388160.

Friberg, Jon Horgen (2012) "Culture at work: Polish migrants in the ethnic division of labour on Norwegian construction sites." Ethnic and Racial Studies (35)11: 1914-1933, doi: $10.1080 / 01419870.2011 .605456$

Griffeth, R. W., Hom, P. W., and Gaertner, S. (2000). "A meta-analysis of antecedents and correlates of employee turnover: Update, moderator tests, and research implications for the next millennium." Journal of Management 26(3): 463-488. doi: 10.1177/014920630002600304.

Hagendoorn, L. (1993) "Ethnic categorization and outgroup exclusion: Cultural values and social stereotypes in the construction of ethnic hierarchies." Ethnic and Racial Studies 16: 27-51.

Hagendoorn, L. (1995). "Intergroup biases in multiple group systems: The perception of ethnic hierarchies." European Review of Social Psychology 6:199-224.

Hasluck, Chris (2011). "Employers and recruitment of unemployed people: An evidence review." UK Commission for Emplyoment and Skills. Briefing Paper, online: http://dera.ioe.ac.uk/13251/1/evidence-review-employers-recruitment-unemployed.pdf, [accessed 31.10.2017]. 
Heckman, J., and Siegelman, P. (1993). "The Urban Institute Audit Studies: Their Methods and Findings." In M. Fix and R. J. Struyk (eds.). Clear and Convincing Evidence: Measurement of Discrimination in America. Washington, D.C.: The Urban Institute Press.

Hout, M., Smith, T. W. and Marsden, P. V. (2010). "Prestige and Socioeconomic Scores for the 2010 Census Codes." GSS Methodological Report No. 124, supplementary data file available at: http://gss.norc.org/Documents/other/PRESTG10SEI10_supplement.xls, [accessed 31.10.2017].

Jiang, K., Liu, D., McKay, P. F., Lee, T. W., and Mitchell, T. R. (2012). "When and How Is Job Embeddedness Predictive of Turnover? A Meta-Analytic Investigation." Journal of Applied Psychology, 97(5): 1077-1096. doi: 10.1037/a0028610.

Meyer, J. P., Stanley, D. J., Jackson, T. A., McInnis, K. J., Maltin, E. R., and Sheppard, L. (2012). "Affective, normative, and continuance commitment levels across cultures: A meta-analysis." Journal of Vocational Behavior 80(2): 225-245. doi: 10.1016/j.jvb.2011.09.005.

Meyer, J., and Allen, N. (1991). "A three-component conceptualization of organizational committement." Human resource management review 1:61-89.

Moss, Philip and Tilly, Chris (2001). Stories Employers Tell: Race Skill, and Hiring in America, New York: Russel Sage Foundation.

Oberholzer-Gee F. (2008). "Nonemployment stigma as rational herding: A field experiment." Journal of Economic Behavior and Organization 65(1): 30-40.

Offe, C. and Hinrichs, K. (1985). "The political economy of the labour market." In C. Offe (ed.). Disorganized Capitalism: Contemporary Transformations of Work and Politics. Cambridge: Polity Press: 10-51.

Pager, D., Western, B., and Bonikowski, B. (2009). "Discrimination in a low wage labor market: A field experiment.” American Sociological Review, 74: 777-799. doi: 10.1177/000312240907400505

Piore, M. J. (1979). Birds of Passage: Migrant Labor and Industrial Societies. Cambridge: Cambridge U Press.

Quillian, L.; Pager, D.; Hexel, O. and Midtbøen, Arnfinn (2017). "Meta-analysis of field experiments shows no change in racial discrimination in hiring over time." Proceedings of the National Academy of Sciences 114 (41): 10870-10875, doi: 10.1073/pnas.1706255114.

Raikes, Luke and Bill Davies (2015). "European Employers' perspective on long-term unemployment, recruitment and public employment services", Institute for Public Policy Research, www.ippr.org/publications/european-employers-perspectives-on-long-term-unemploymentrecruitment-and-pes, [accessed 31.10.2017].

Rebien, M. (2010). "The use of social networks in recruiting processes from a firms perspective." IAB, Discussion Paper 5/2010. Nurnberg.

Reich, M., Gordon, D. M., and Edwards, R. C. (1973). "A Theory of Labor Market Segmentation." American Economic Review 63: 359-365.

Riach, P. A., and J. Rich (2002). "Field Experiments of Discrimination in the Market Place." The Economic Journal 112: 480-518.

Rich, Judith (2014). “A Meta Analysis of Studies Conducted since 2000.” IZA Discussion Paper, No. 8584 .

Rooth, Dan-Olof (2012). "Obesity, Attractivness, and Differential Treatment in Hiring.” The Journal of Human Resources 44 (3): 710-35.

Rusbult, C. E., and Farrell, D. (1983). "A longitudinal test of the investment model - the impact on job-satisfaction, job commitment, and turnover of variations in rewards, costs, alternatives, and investments." Journal of Applied Psychology, 68(3), 429-438. doi: 10.1037/00219010.68.3.429. 
Shapiro, C. and Stiglitz, J. E. (1984). "Equilibrium Unemployment as a Worker Discipline Device." The American Economic Review, 74(3): 433-444.

Shih, Johanna (2002) “'...Yeah, I could hire this one, but I know it's gonna be a problem': how race, nativity and gender affect employers' perceptions of the manageability of job seekers." Ethnic and Racial Studies, 25(1): 99-119, DOI: 10.1080/01419870120112076.

Vandenberghe, C. (2015). "Le rôle des interactions entre engagements multiples dans la prédiction du risque de démission. » Relations industrielles/Industrial relations 70(1): 62-85.

Waldinger, R. and Lichter, M. I. (2003). How the Other Half Works: Immigration and the Social Organization of Labor. Berkeley: University of California Press

Zamudio, M.M. and Lichter, I.M. (2008). "Bad Attitudes and Good Soldiers: Soft Skills as a Code for Tractability in the Hiring of Immigrant Latina/os over Native Blacks in the Hotel Industry." Social Problems 55: 573-589.

Zschirnt, E., and Ruedin, D. (2016). "Ethnic Discrimination in Hiring Decisions: a Meta-Analysis of Correspondence Tests 1990-2015." Journal of Ethnic and Migration Studies 42(7): 1115-1134. 


\section{Tables and Figures}

Figure 1: Theoretical model of the relationship between minority preference and gross discrimination. Dots represent estimates of discrimination obtained in correspondence tests

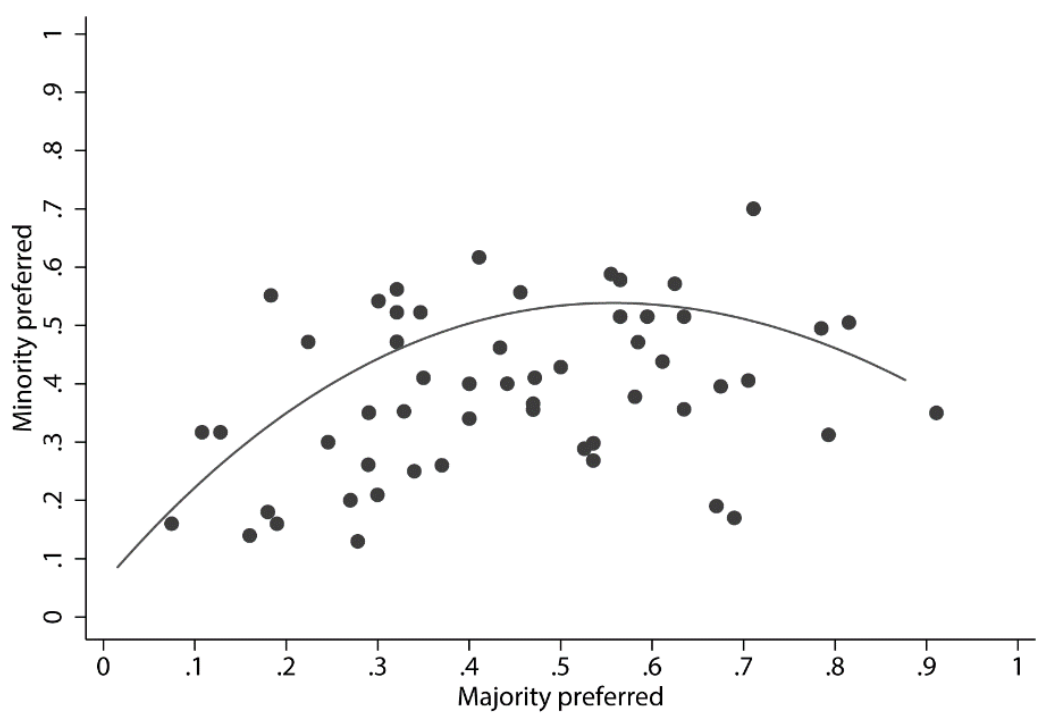


Figure 2: Relationship between the gross discrimination and minority preference

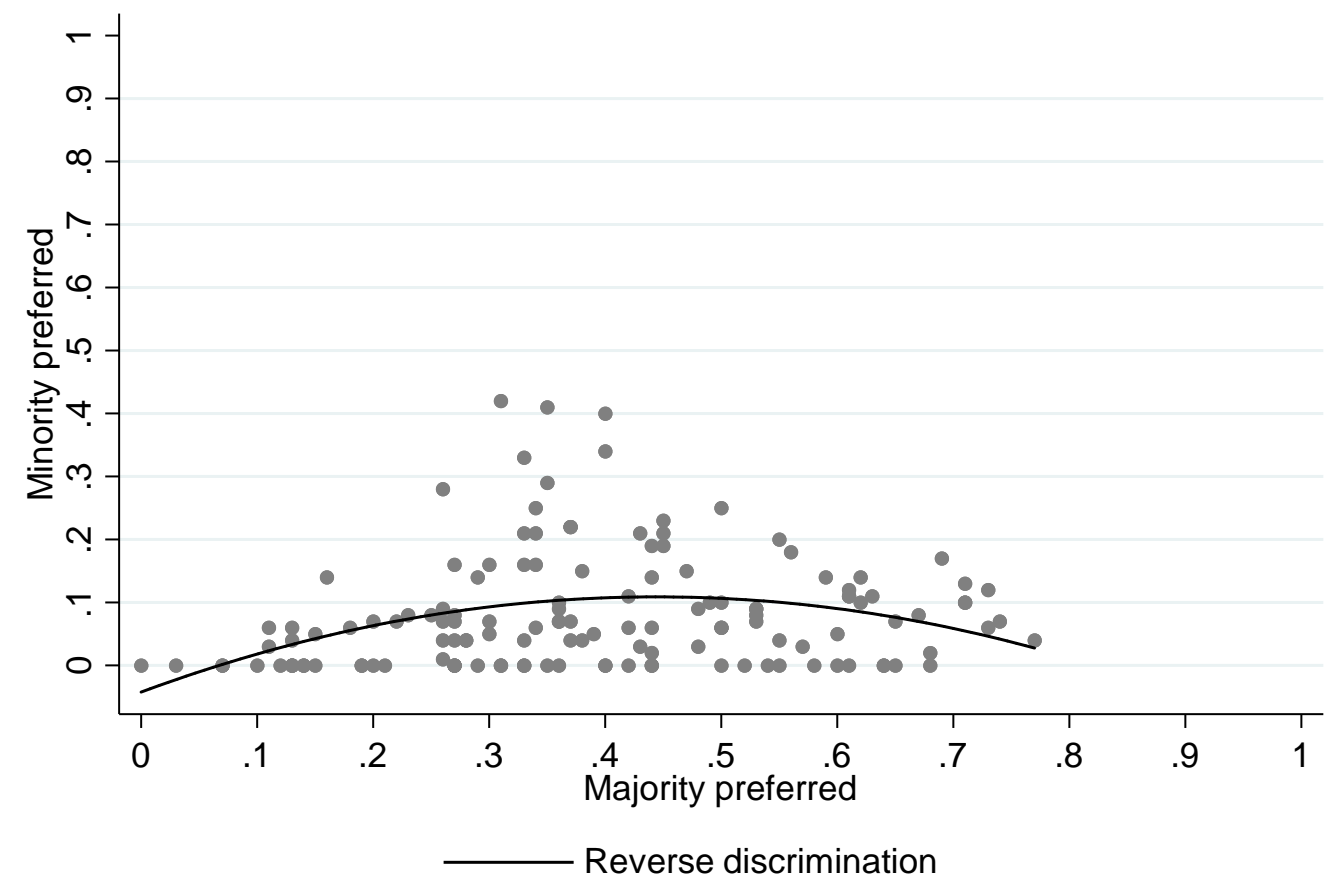

Quadratic fit, N=139 
Table 1: Multilevel models of the minority preference rate

\begin{tabular}{|c|c|c|c|c|c|c|}
\hline & Model 1 & & Model 2 & & odel 3 & \\
\hline $\begin{array}{l}\text { Preference } \\
\text { majority }\end{array}$ & $0.578 * *$ & (0.170) & 0.571* & $(0.212)$ & 0.359* & $(0.151)$ \\
\hline $\begin{array}{l}\text { Preference } \\
\text { majority^2 }\end{array}$ & $-0.625^{*}$ & $(0.228)$ & $-0.625^{*}$ & $(\mathbf{0 . 2 7 8 )}$ & $-0.326+$ & $(0.167)$ \\
\hline $\begin{array}{l}\text { Prestige score } \\
\text { Managers } \\
\text { (ref) }\end{array}$ & & & 0.001 & $(0.001)$ & & \\
\hline Professionals & & & & & -0.036 & $(0.034)$ \\
\hline $\begin{array}{l}\text { Technicians } \\
\text { and associate } \\
\text { professionals }\end{array}$ & & & & & $-0.134 * * *$ & $(0.032)$ \\
\hline $\begin{array}{l}\text { Clerical } \\
\text { support } \\
\text { workers }\end{array}$ & & & & & -0.015 & $(0.065)$ \\
\hline $\begin{array}{l}\text { Services and } \\
\text { sales workers }\end{array}$ & & & & & $-0.107^{*}$ & $(0.036)$ \\
\hline $\begin{array}{l}\text { Craft and } \\
\text { related trades } \\
\text { workers }\end{array}$ & & & & & $-0.143 * *$ & $(0.038)$ \\
\hline $\begin{array}{l}\text { Plant and } \\
\text { machine } \\
\text { operators and } \\
\text { assemblers }\end{array}$ & & & & & $-0.118 * *$ & $(0.037)$ \\
\hline $\begin{array}{l}\text { Elementary } \\
\text { occupations }\end{array}$ & & & & & $-0.122 * *$ & $(0.035)$ \\
\hline Constant & $-0.028^{*}$ & $(0.010)$ & $-0.088^{*}$ & $(0.038)$ & $0.092 *$ & $(0.043)$ \\
\hline $\begin{array}{l}\text { Log- } \\
\text { Likelihood }\end{array}$ & 142.12 & & 135.55 & & 157.73 & \\
\hline $\begin{array}{l}\text { Log- } \\
\text { Likelihood } \\
\text { null model }\end{array}$ & 134.71 & & 125.86 & & 130.42 & \\
\hline $\mathrm{N}$ & 139 & & 131 & & 135 & \\
\hline Studies & 15 & & 15 & & 15 & \\
\hline
\end{tabular}

Standard errors in parentheses

$+\mathrm{p}<0.10, * \mathrm{p}<0.05, * * \mathrm{p}<0.01, * * * \mathrm{p}<0.001$ 


\section{Appendix}

Table A1: Estimation details for European Social Survey 2010

\section{Data and sample}

We use data from the European Social Survey Round 5 for the year 2010 (ESS 2010).

As most of the correspondence testings have been carried out in the US or in Western Europe, we run our analyses on a similar sample of countries. From the 27 countries we retain 12 Western European countries, namely, namely Belgium, Switzerland, Germany, Denmark, Spain, Finland, France, Great Britain, Ireland, the Netherlands, Norway and Sweden. ${ }^{14}$

\section{Dependent variable}

The dependent variable is 'How difficult/easy is it to get a similar or better job if you had to leave your current employer' (variable smblvib). The answer is gauged on a scale between 0 'extremely difficult' and 10 'extremely easy', which we reverse meaning that high values correspond to difficulties finding an alternative position.

\section{Independent variable}

To capture minority status, we use the variable $d s c r g r p$ which asks whether the respondent is member of a group that is discriminated against in the country of residence (yes/no).

\section{Control variables}

We control for age in years (agea), which we recode into six groups (less than 18, 18-24, 25-34, 35-44, 45-54, and 55-65 years), gender with reference category being male (gndr), a continuous variable capturing the number of members living in the household (hhmmb), and citizenship distinguishing between foreigner and national (ctzcntr). We use the International Standard Classification of Education (ISCED) to capture educational outcome (eisced) and control for the income decile (hinct).

To control for underemployment as a determinant of the wish to change employer, we include a measure of the hours a person would chose to work weekly if he/she could choose ('How many hours would you choose to work weekly', whhsch).

To control for difficulties finding other employment due to health-related issues, we control for the subjective assessment of a person's health (health) gauged on a scale from very good $(=1)$ to very bad $(=5)$.

Moreover, we control for firmsize (estsz) distinguishing very small $(<10)$, small $(10-24)$, medium $(25-$ $99)$, large $(100-500)$ and very large firms $(<500)$. We capture the sector of employment using the 1-digit ISCO-88 classification that distinguishes between managers, professionals, technicians and associate professionals, clerks, service workers and shop and market sales workers, skilled agricultural and fishery workers, craft and related trade workers, plant and machine operators and assemblers, elementary occupations, and armed forces.

\section{Estimation}

To account for the nested data structure we run multilevel models, however, as we have only 12 higher level units we also estimated OLS regressions with clustered standard errors and the results remain the same.

\section{Robustness}

We replicate these analyses also with EES 02 data for 2004 (ESS 2004) which has a different country sample and a slightly different dependent variable. The countries included are Austria, Belgium, Switzerland, Germany, Denmark, Finland, Great Britain, Ireland, Luxembourg, the Netherlands, Norway, and Sweden. The dependent variable asks 'How easy/difficult is it to get a similar or better job with another employer'. The results are robust with these data (results not shown but available upon request).

\footnotetext{
${ }^{14}$ We exclude Bulgaria, Cyprus, Czechia, Estonia, Greece, Hungary, Croatia, Israel, Lithuania, Poland, Portugal, Romania, Slovenia, Slovakia and Ukranine.
} 
Table A2: Determinants of perceived job alternatives

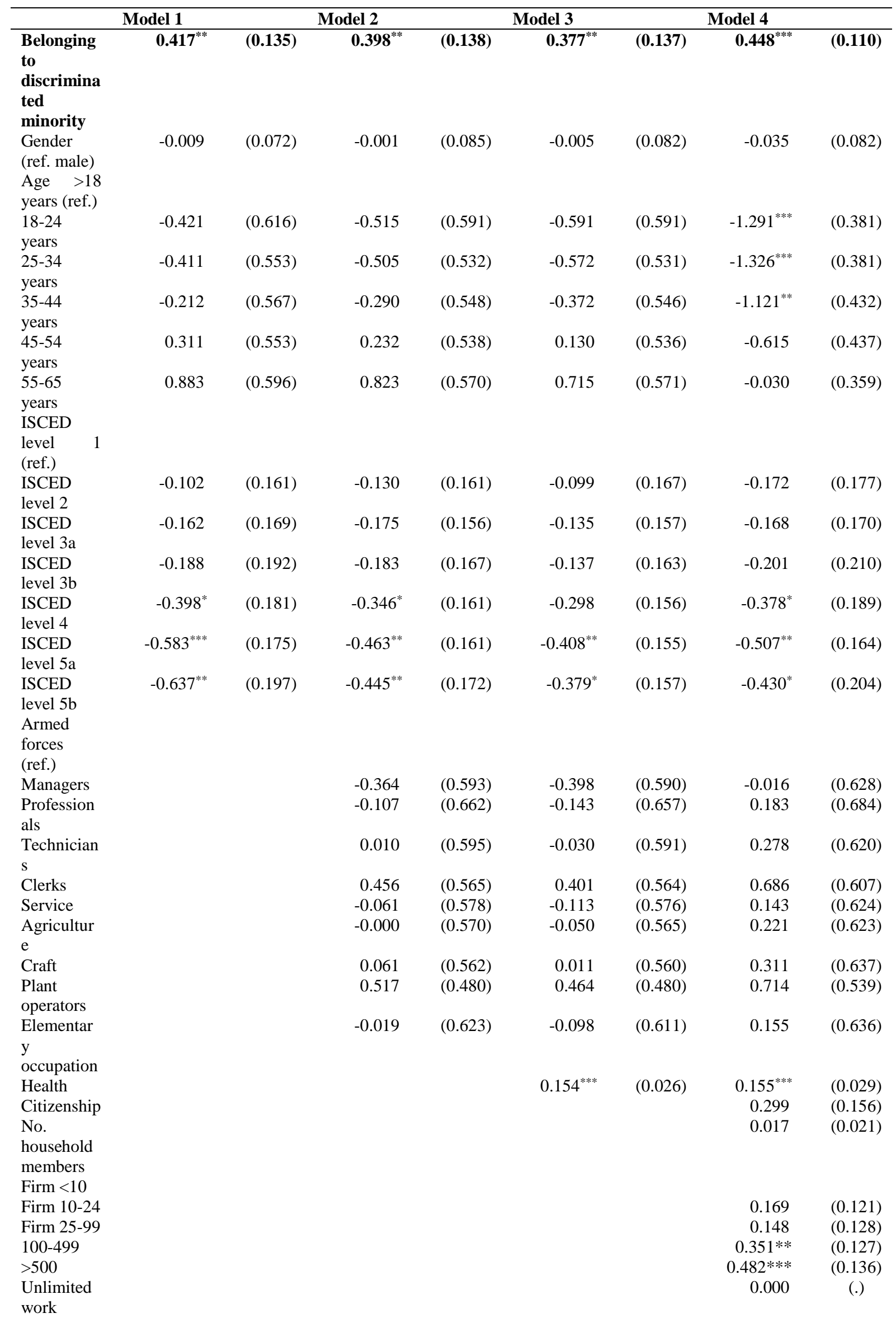




\begin{tabular}{|c|c|c|c|c|c|c|c|c|}
\hline $\begin{array}{l}\text { Limited } \\
\text { contract }\end{array}$ & & & & & & & 0.090 & $(0.111)$ \\
\hline $\begin{array}{l}\text { No } \\
\text { contract }\end{array}$ & & & & & & & 0.426 & $(0.266)$ \\
\hline $\begin{array}{l}\text { Wished } \\
\text { working } \\
\text { hours }\end{array}$ & & & & & & & -0.001 & $(0.004)$ \\
\hline $\begin{array}{l}\text { Income } \\
\text { decile }\end{array}$ & & & & & & & $-0.056 * * *$ & $(0.009)$ \\
\hline Constant & $5.354 * * *$ & $(0.588)$ & $5.351 * * *$ & $(0.865)$ & $5.147 * * *$ & $(0.850)$ & $5.528 * * *$ & $(0.815)$ \\
\hline $\begin{array}{l}\text { Variance } \\
\text { individual } \\
\text { level }\end{array}$ & 7.084 & 0.269 & 7.042 & 0.187 & 7.025 & 0.266 & 6.925 & 0.288 \\
\hline $\begin{array}{l}\text { Variance } \\
\text { country } \\
\text { level }\end{array}$ & 0.465 & 0.181 & 0.465 & 0.187 & 0.463 & 0.196 & 0.435 & 0.192 \\
\hline 11 & -20353.69 & & -20204.52 & & -20177.79 & & -17389.35 & \\
\hline AIC & 40729.38 & & 40431.04 & & 40377.59 & & 34800.70 & \\
\hline BIC & 40806.91 & & 40508.51 & & 40455.05 & & 34876.71 & \\
\hline $\begin{array}{l}\mathrm{N} \\
\text { individual } \\
\text { level }\end{array}$ & 8503 & & 8454 & & 8448 & & 7403 & \\
\hline Countries & 12 & & 12 & & 12 & & 12 & \\
\hline
\end{tabular}

Standard errors in parentheses

$* \mathrm{p}<0.05, * * \mathrm{p}<0.01, * * * \mathrm{p}<0.001$ 


\section{Supplementary material}

Table S1: Meta-analyse used to identify the correspondence testing

\begin{tabular}{l|l}
\hline 1 & Bertrand, M. and Duflo, E. (2016) 'Field Experiments on Discrimination' NBER Working Paper, No. 22014. \\
\hline 2 & $\begin{array}{l}\text { Riach, P. A. and Rich, J. (2002) 'Field Experiments of Discrimination in the Market Place The Economic } \\
\text { Journal 112: 480-518. }\end{array}$ \\
\hline 3 & Rich, J. (2014) ‘A Meta-Analysis of Studies Conducted since 2000’ IZA Discussion Paper, No. 8584. \\
\hline 4 & $\begin{array}{l}\text { Zschirnt, E. and Ruedin, D. (2016) 'Ethnic Discrimination in Hiring Decisions: a Meta-Analysis of } \\
\text { Correspondence Tests 1990-2015'Journal of Ethnic and Migration Studies 42(7): 1115-1134. }\end{array}$ \\
\hline
\end{tabular}

Table S2: Correspondence testing on labour market access of applicants with foreign ethnicity/nationality that were included in the analysis

\begin{tabular}{|c|c|}
\hline 1 & $\begin{array}{l}\text { Akintola, A. R. (2011) Hiring Discrimination in Racially Diverse Labour Markets: A Cross Country Study, } \\
\text { Master Thesis, Karstad Business School. }\end{array}$ \\
\hline 2 & $\begin{array}{l}\text { Allasino, E., Reyneri, E., Venturini, A., and Zincone, G. (2006) 'Labour Market Discrimination against Migrant } \\
\text { Workers in Italy’ ILO International Migration Papers, No. 67, Geneva: ILO. }\end{array}$ \\
\hline 3 & $\begin{array}{l}\text { Andriessen, I., Nievers, E., Dagevos, J., and Faulk, L. (2012) 'Ethnic Discrimination in the Dutch Labor Market: } \\
\text { Its Relationship With Job Characteristics and Multiple Group Membership' Work and Occupations 39(3): } 237 \\
269 .\end{array}$ \\
\hline 4 & $\begin{array}{l}\text { Arai, M., Bursell, M., and Nekby, L. (2016) ‘The Reverse Gender Gap in Ethnic Discrimination: Employer } \\
\text { Stereotypes of Men and Women with Arabic Names' International Migration Review 50(2): 385-412. }\end{array}$ \\
\hline 5 & $\begin{array}{l}\text { Baert, S., Cockx, B., Gheyle, N., and Vandamme, C. (2013) 'Is There Less Discrimination in Occupations Where } \\
\text { Recruitment Is Difficult? ILR Review 68(3): 467-500. }\end{array}$ \\
\hline 6 & $\begin{array}{l}\text { Bovenkerk, F., Kilborne, B., Raveau, F., and Smith, D. (1979) 'Comparative aspects of research on discrimination } \\
\text { against non-white citizens in Great Britain, France and the Netherlands', in J. Berting, F. Geyer and Jurkovich, R. } \\
\text { (eds), Problems in International Comparative Research in the Social Sciences. Oxford: Pergamon Press. Data as } \\
\text { indicated in Riach and Rich (2002). }\end{array}$ \\
\hline 7 & $\begin{array}{l}\text { Bovenkerk, F., Gras, M. J. I., Ramsoedh, D., Dankoor, M. and Havelaar, A. (1995) Discrimination Against } \\
\text { Migrant Workers and Ethnic Minorities in Access to Empoyment in the Netherlands. Geneva: Employment } \\
\text { Department, International Labour Office. }\end{array}$ \\
\hline 8 & $\begin{array}{l}\text { Bursell, M. (2007) 'What's in a Name? - A Field Experiment Test for the Existence of Ethnic Discrimination in } \\
\text { the Hiring Process' SULCIS Working Paper, No. 7: 1-28. }\end{array}$ \\
\hline 9 & $\begin{array}{l}\text { Bursell, M. (2014) 'The Multiple Burdens of Foreign-Named Men - Evidence from a Field Experiment on } \\
\text { Gendered Ethnic Hiring Discrimination in Sweden' European Sociological Review 30(3):399-409. }\end{array}$ \\
\hline 10 & $\begin{array}{l}\text { Carlsson, M., and Rooth, D.-O. (2007) 'Evidence of Ethnic Discrimination in the Swedish Labor Market Using } \\
\text { Experimental Data' Labour Economics 14(4): 716-729. }\end{array}$ \\
\hline 11 & $\begin{array}{l}\text { Cédiey, E., and Foroni, F. (2007) ‘Les discriminations à raison de 'l'origine' dans les embauches en France. Une } \\
\text { enquête nationale par tests de discrimination selon la méthode du Bureau International du Travail. Genève: Bureau } \\
\text { International du Travail. Data as indicated in Rich (2014). }\end{array}$ \\
\hline 12 & $\begin{array}{l}\text { Drydakis, N. (2012) 'Estimating Ethnic Discrimination in the Labour Market Using Experimental Data' } \\
\text { Southeast European and Black Sea Studies 12(2): 335-355. }\end{array}$ \\
\hline 13 & $\begin{array}{l}\text { Drydakis, N., and Vlassis, M. (2010) 'Ethnic Discrimination in the Greek Labour Market: Occupational Access, } \\
\text { Insurance Coverage and Wage Offers' The Manchester School 78(3): 201-218. }\end{array}$ \\
\hline 14 & $\begin{array}{l}\text { Eid, P. (2012) Mesurer la discrimination à l'embauche subie par les minorités racisées: résultats d'un testing' } \\
\text { mené dans le grand Montréal. Quebec: Commission des droits de la personne et des droits de la jeunesse. }\end{array}$ \\
\hline 15 & $\begin{array}{l}\text { Esmail, A., and Everington, S. (1993) 'Racial Discrimination against Doctors from Ethnic Minorities' British } \\
\text { Medical Journal } 306 \text { (6879):691-692. Data as indicated in Riach and Rich (2002). }\end{array}$ \\
\hline 16 & $\begin{array}{l}\text { Esmail, A., and Everington, S. (1997) 'Asian Doctors are Still Being Discriminated against' British Medical } \\
\text { Journal 314(7094): 618-619. Data as indicated in Riach and Rich (2002). }\end{array}$ \\
\hline 17 & $\begin{array}{l}\text { Fibbi, R., Kaya, B., and Piguet, E. (2003) 'Le Passeport ou le Diplôme? Étude des Discriminations à l'Embauche } \\
\text { des Jeunes issus de la Migration' PNR } 43 \text { Rapport de recherche au FNS. Neuchâtel: Forum Suisse pour l'Étude } \\
\text { des Migrations et de la Population. }\end{array}$ \\
\hline 18 & $\begin{array}{l}\text { Firth, M. (1981) 'Racial discrimination in the British labour market' Industrial and Labor Relations Review 34: } \\
\text { 265-72. Data as indicated in Riach and Rich (2002). }\end{array}$ \\
\hline
\end{tabular}




\begin{tabular}{c|l}
\hline 19 & $\begin{array}{l}\text { Goldberg, A., Mourinho, D. and Kulke, U. (1995) Labour Market Discrimination against Foreign Workers in } \\
\text { Germany. International Labour Office, Employment Department. }\end{array}$ \\
\hline 20 & $\begin{array}{l}\text { Hubbuck, J., and Carter, S. (1980) Half a Chance? A Report on Job Discrimination against Young Blacks in } \\
\text { Nottingham. London: Commission for Racial Equality. Data as indicated in Riach and Rich (2002). }\end{array}$ \\
\hline 21 & $\begin{array}{l}\text { Jowell, R., and Prescott-Clarke, P. (1970) 'Racial discrimination and white-collar workers in Britain' Race 11: } \\
\text { 397-417. Data as indicated in Riach and Rich (2002). }\end{array}$ \\
\hline 22 & $\begin{array}{l}\text { Kaas, L., and Manger C. (2011) ‘Ethnic Discrimination in Germany's Labour Market: A Field Experiment' } \\
\text { German Economic Review 13(1): 1-20. }\end{array}$ \\
\hline 23 & $\begin{array}{l}\text { Maurer-Fazio, M. (2012) ‘Ethnic Discrimination in China's Internet Job Board Labor Market' IZA Journal of } \\
\text { Migration 1(12): 1-24. }\end{array}$ \\
\hline 24 & $\begin{array}{l}\text { McGinnity, F., and Lunn, P. D. (2011) 'Measuring Discrimination Facing Ethnic Minority Job Applicants: An } \\
\text { Irish Experiment' Work, Employment and Society 25(4): 693-708. }\end{array}$ \\
\hline 25 & $\begin{array}{l}\text { McIntosh, N. and Smith, D. (1974) 'The Extent of Racial Discrimination' Political and Economic Planning } \\
\text { Broadsheet, No. 547, London: Political and Economic Planning. Data as indicated in Riach and Rich (2002). }\end{array}$ \\
\hline 26 & $\begin{array}{l}\text { Midtbøen, A. H. (2016) ‘Discrimination of the Second Generation: Evidence from a Field Experiment in } \\
\text { Norway’ International Migration and Integration 17(1): 253-272. }\end{array}$ \\
\hline 27 & $\begin{array}{l}\text { Riach, P. and Rich, J. (1991) ‘Testing for racial discrimination in the labour market', Cambridge Journal of } \\
\text { Economics 15: 239-56. Data as indicated in Riach and Rich (2002). }\end{array}$ \\
\hline 28 & $\begin{array}{l}\text { Widner, D., and S. Chicoine (2011) 'It's All in the Name: Employment Discrimination Against Arab Americans' } \\
\text { Sociological Forum 26(4): 806-823. }\end{array}$ \\
\hline 29 & $\begin{array}{l}\text { Wysienska-Di Carlo, K. and Karpinski, Z. (2014) 'Discrimination facing immigrant job applicants in Poland - } \\
\text { results of a field experiment', XVIII ISA World Congress of Sociology, July 13-19. Data as indicated in Rich } \\
\text { (2014). }\end{array}$ \\
\hline
\end{tabular}


Table S3: Correspondence testing and other experiments $\underline{\text { not }}$ included in the analysis

Identified correspondence studies that do not provide call back for minority/majority only and/or group specific $\mathbf{N}$

$1 \quad$ Agerström, J., Björklund, F., Carlsson, R. and Rooth, D.-O. (2012) 'Warm and Competent Hassan = Cold and Imcompetent Eric: A Harsh Equation of Real-Life Hiring Discrimination' Basic and Applied Social Psychology 34(4): 359-366.

2 Ariel, B., Tobby-Alimi, I., Cohen, I., Ezra, M. B., Cohen, Y., and Sosinski G. (2015) 'Ethnic and Racial Employment Discrimination in Low-Wage and High-Wage Markets: Randomized Controlled Trials Using Correspondenc Tests in Israel' Law and Ethics of Human Rights 9(1): 113-139.

3 Bartoš, V., Bauer. M., Chytilov, J., and Matejka F. (2014) 'Attention Discrimination: Theory and Field Experiments' CERGE Working Paper.

$4 \quad$ Bendick Jnr., M., Jackson, C., Reinoso, V., and Hodges, L. (1991) 'Discrimination against Latino job applicants: a controlled experiment' Human Resource Management 30: 469-84.

$5 \quad$ Bertrand, M., and Mullainathan, S. (2004) 'Are Emily and Greg More Employable than Lakisha and Jamal? A Field Experiment on Labor Market Discrimination' The American Economic Review 94(4): 991-1013.

$6 \quad$ Birkelund, G. E., Heggeb $\varnothing$, K., and Rogstad, J. (2017) 'Additive or Multiplicative Disadvantage? The Scarring Effects of Unemployment for Ethnic Minorities’ European Sociological Review 33(1): 17-29.

7 Blommaert, L., and Coenders, M. (2013) 'Discrimination of Arabic-Named Applicants in the Netherlands: An Internet-Based Field Experiment Examining Different Phases in Online Recruitment Procedures' Social Forces 92(3): 957-982.

8 Booth, A. L., Leigh, A., and Varganova, E. (2012) 'Does Ethnic Discrimination Vary Across Minority Groups? Evidence from a Field Experiment' Oxford Bulletin of Economics and Statistics 74(4): 547-573.

9 Carlsson, M. (2010) 'Experimental Evidence of Discrimination in the Hiring of First- and Second-generation Immigrants' Labour 24(3), 263-278.

10 Carlsson, M., Fumarco, L., and Rooth, D.-O. (2015) 'Does Labor Market Tightness Affect Ethnic Discrimination in Hiring?' Linnaeus University, Labour Market and Discrimination Studies Centre, Working Paper, No.1.

11 Decker, S. H., Ortiz, N., Spohn, C., and Hedberg, E. (2015) 'Criminal Stigma, Race, and Ethnicity: The Consequences of Imprisonment for Employment' Journal of Criminal Justice 43(2): 108-121.

12 Duguet, E., Du Parquet, L., L'Horty, Y., and Petit, P. (2012) 'New Evidence of Ethnic and Gender Discriminations in the French Labor Market using Experimental Data: A Ranking Extension of Correspondence Testings' TEPP Working Paper, No. 16.

13 Gaddis, S. M. (2015) 'Discrimination in the Credential Society: An Audit Study of Race and College Selectivity in the Labor Market' Social Forces 93(4): 1451-1479.

14 Galarza, F. B., and Yamada, G. (2014) 'Labor Market Discrimination in Lima, Peru: Evidence from a Field Experiment' World Development 58: 83-94.

15 Jacquemet, N., and Yannelis, C. (2012) 'Indiscriminate Discrimination: A Correspondence Test for Ethnic Homophily in the Chicago Labor Market' Labour Economics 19(6), 824-832.

16 Jolson, M. A. (1974) 'Employment Barriers in Marketing’ Journal of Marketing 38(2): 67.

17 Jowell, R., and Prescott-Clarke, P. (1970) 'Racial Discrimination and White-Collar Workers in Britain' Race and Class 11(4): 397-417.

18 Neumark, D. (2010) 'Detecting Discrimination in Audit and Correspondence Studies' NBER Working Paper Series, No. 16448.

19 Nunley, J. M., Pugh, A., Romero, N., and Seals, R. A. Jr. (2014) 'An Examination of Racial Discrimination in the Labor Market for Recent College Graduates: Estimates from the Field' Working Paper Series, No. 6. Department of Economics, Auburn University.

20 Oreopoulos, P. (2011) 'Why Do Skilled Immigrants Struggle in the Labor Market? A Field Experiment with Thirteen Thousand Resumes' American Economic Journal: Economic Policy 3(4): 148-171.

21 Oreopoulos, P., and Dechief, D. (2012) 'Why do some Employers Prefer to Interview Matthew but not Samir? New Evidence from Toronto, Montreal and Vancouver' Canadian Labour Market and Skills Researcher Network, Working Paper No. 95.

22 Petit, P., Duguet, E., L'Horty, Y., Du Parquet, L., and Sari, F. (2011) 'Discriminations à l'Embauche des Jeunes Franciliens et Intersectionalité du Sexe et de l'Origine: les Résultats d'un Testing' TEPP Rapport de Recherche No. 5.

23 Schneider, J., Yemane, R., and Weinmann, M. (2014) Diskriminierung am Ausbildungsmarkt: Ausmass, Ursachen und Handlungsperspektiven. Berlin Forschungsbereich beim Sachverständigenrat deutscher Stiftungen für Integration und Migration (SVR). 


\begin{tabular}{|c|c|}
\hline 24 & $\begin{array}{l}\text { Weichselbaumer, D. (2015) 'Discrimination against Migrants in Austria: An Experimental Study' IZA } \\
\text { Discussion Paper, No. } 9354 \text {. }\end{array}$ \\
\hline \multirow[t]{2}{*}{25} & $\begin{array}{l}\text { Wood, M., Hales, J., Purdon, S., Sejersen, T., and Hayllar, O. (2009) ‘A Test for Racial Discrimination in } \\
\text { Recruitment Practice in British Cities’ Department for Work and Pensions, Research Report No. 607: 1-69. }\end{array}$ \\
\hline & Audit and internet based studies, other field experiments \\
\hline 1 & $\begin{array}{l}\text { Arceo-Gómez, E. O., and Campos-Vazquez, R. M. (2013) 'Race and Marriage in the Labor Market: A } \\
\text { Discrimination Audit Study in a Developing Country' Serie documentos de trabajo del Centro de Estudios } \\
\text { Económicos. El Colegio de Mexico, Centro de Estudios Económicos. }\end{array}$ \\
\hline 2 & $\begin{array}{l}\text { Arrijn, P., Feld, S., and Nayer, A. (1998) 'Discrimination in access to employment on grounds of foreign origin } \\
\text { the case of Belgium' International Migration Papers 23, Geneva. International Labour Office. }\end{array}$ \\
\hline 3 & $\begin{array}{l}\text { Attström, K. (2007) 'Discrimination against native Swedes of immigrant origin in access to employment' } \\
\text { International Migration Papers } 86 E \text {, Geneva: International Labour Office. }\end{array}$ \\
\hline 4 & $\begin{array}{l}\text { Bendick, M., Jackson, C. W., Reinoso, V. A., and Hodges, L. E. (1991) 'Discrimination against latino job } \\
\text { applicants: A controlled experiment' Human Resource Management 30(4): 469-484. }\end{array}$ \\
\hline 5 & $\begin{array}{l}\text { Blommaert, L., Coenders, M., and van Tubergen, F. (2014) Discrimination of Arabic-Named Applicants in } \\
\text { the Netherlands. An Internet-Based Field Experiment Examining Different Phases in Online Recruitment } \\
\text { Procedures' Social Forces 92(3): 957-982. }\end{array}$ \\
\hline 6 & $\begin{array}{l}\text { Diekmann, A., Jann, B., and Näf, M. (2014) 'Wie fremdenfeindlich ist die Schweiz? Fünf Feldexperimente } \\
\text { über prosoziales Verhalten und die Diskriminierung von Ausländern in der Stadt Zürich und in der } \\
\text { Deutschschweiz' Soziale Welt 65: 185-199. }\end{array}$ \\
\hline 7 & $\begin{array}{l}\text { Ford, R. (2015) Who Should We Help? An Experimental Test of Discrimination in the British Welfare State } \\
\text { Political Studies 64(3): 630-650. }\end{array}$ \\
\hline 8 & $\begin{array}{l}\text { Heckmann, J. J., and Siegelmann, P. (1993) 'The Urban Institute Audit Studies: Their Methods and Findings' } \\
\text { Chp. 5. In M. Fix, and Struyk, R.(eds.) Clear and Convincing Evidence: Measurements of Discrimination in } \\
\text { America. Washington, DC: The Urban Institute Press. }\end{array}$ \\
\hline 9 & $\begin{array}{l}\text { Pager, D., Western, B., and Bonikowski, B. (2009) 'Discrimination in a Low-Wage Labor Market: A Field } \\
\text { Experiment' American Sociological Review 74(5): 777-799. }\end{array}$ \\
\hline \multirow[t]{2}{*}{10} & $\begin{array}{l}\text { Prada, M. de, Actis, W., Pereda, C. and Perez Molina, R. (1996) ‘Labour market discrimination against migrant } \\
\text { workers in Spain’ International Migration Papers 9, Geneva: International Labour Office. }\end{array}$ \\
\hline & Religion \\
\hline 1 & $\begin{array}{l}\text { Adida, C. L., Laitin, D. D., and Valfort, M.-A. (2010) 'Identifying Barriers to Muslim Integration in France' } \\
\text { Proceedings of the National Academy of Sciences 107(52): 22384-22390. }\end{array}$ \\
\hline 2 & $\begin{array}{l}\text { Banerjee, A., Bertrand, M., Datta, S., and Mullainathan, S. (2009) 'Labor Market Discrimination in Delhi: } \\
\text { Evidence from a Field Experiment' Journal of Comparative Economics 37(1): 14-27. }\end{array}$ \\
\hline 3 & $\begin{array}{l}\text { Drydakis, N. (2010) 'Religious Affiliation and Employment Bias in the Labor Market' Journal for the Scientific } \\
\text { Study of Religion 49(3): 477-493. }\end{array}$ \\
\hline 4 & $\begin{array}{l}\text { Weichselbaumer, D. (2016) 'Discrimination against Female Migrants Wearing Headscarves' IZA Discussion } \\
\text { Paper, No. } 10217 .\end{array}$ \\
\hline 5 & $\begin{array}{l}\text { Wright, B. R. E., Wallace, M., Bailey, J., and Hyde, A. (2013) 'Religious Affiliation and Hiring } \\
\text { Discrimination in New England: A Field Experiment' Research in Social Stratification and Mobility 34: 111- } \\
126 .\end{array}$ \\
\hline
\end{tabular}


Table S4: Estimations with extended dataset

\begin{tabular}{|c|c|c|}
\hline \multicolumn{3}{|c|}{ Model 1} \\
\hline $\begin{array}{l}\text { Preference } \\
\text { majority }\end{array}$ & $0.456^{* * * *}$ & $\begin{array}{l}(0.109) \\
\end{array}$ \\
\hline $\begin{array}{l}\text { Preference } \\
\text { majority^2 }\end{array}$ & $-0.506^{* *}$ & $(0.153)$ \\
\hline Constant & -0.003 & $(0.013)$ \\
\hline Log-likelihood & 285.50 & \\
\hline $\begin{array}{l}\text { Log-likelihood } \\
\text { null model }\end{array}$ & 275.23 & \\
\hline$N$ & 249 & \\
\hline$N$ studies & 29 & \\
\hline
\end{tabular}


Figure S1: Majority and minority preference in the extended sample

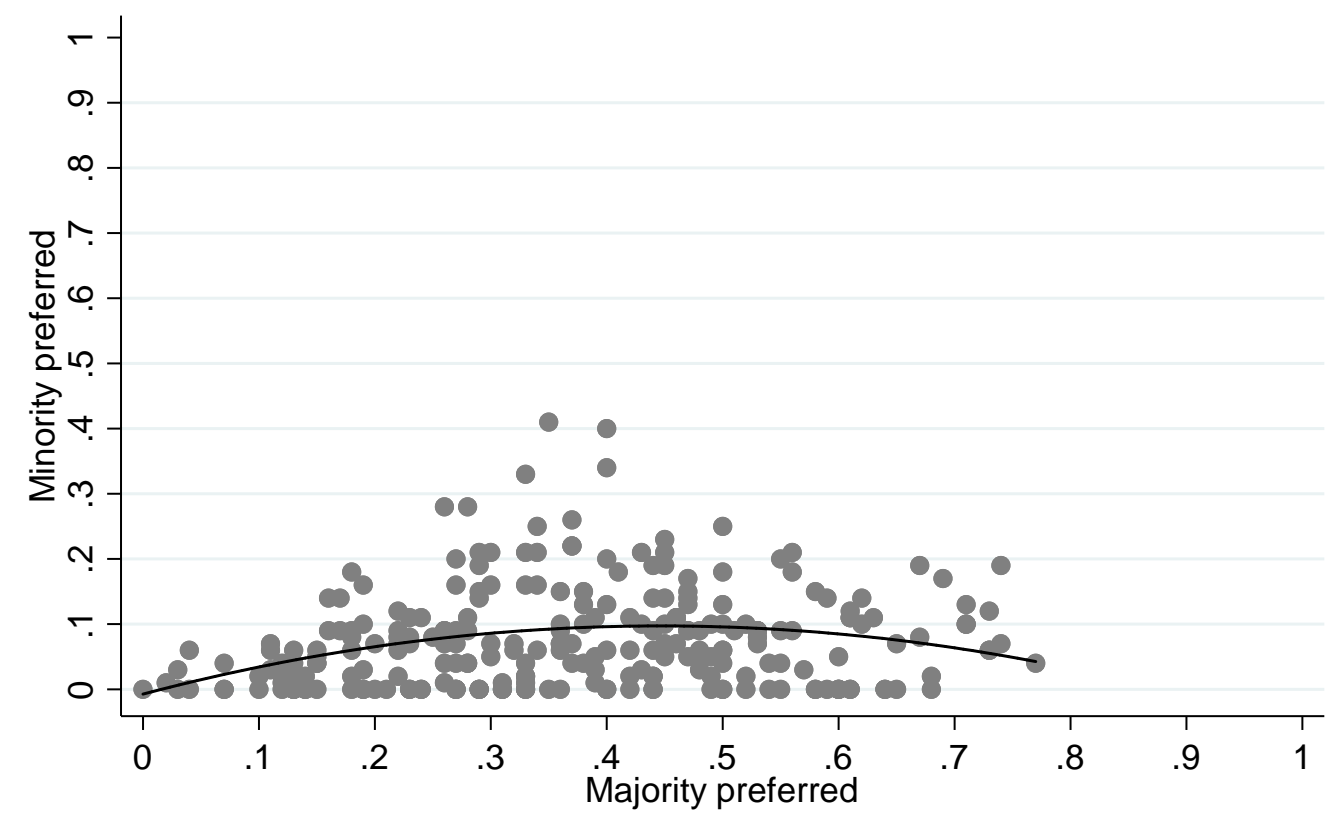

Quadratic fit, $\mathrm{N}=249$ 
Figure S2: Majority and minority preference in the extended sample

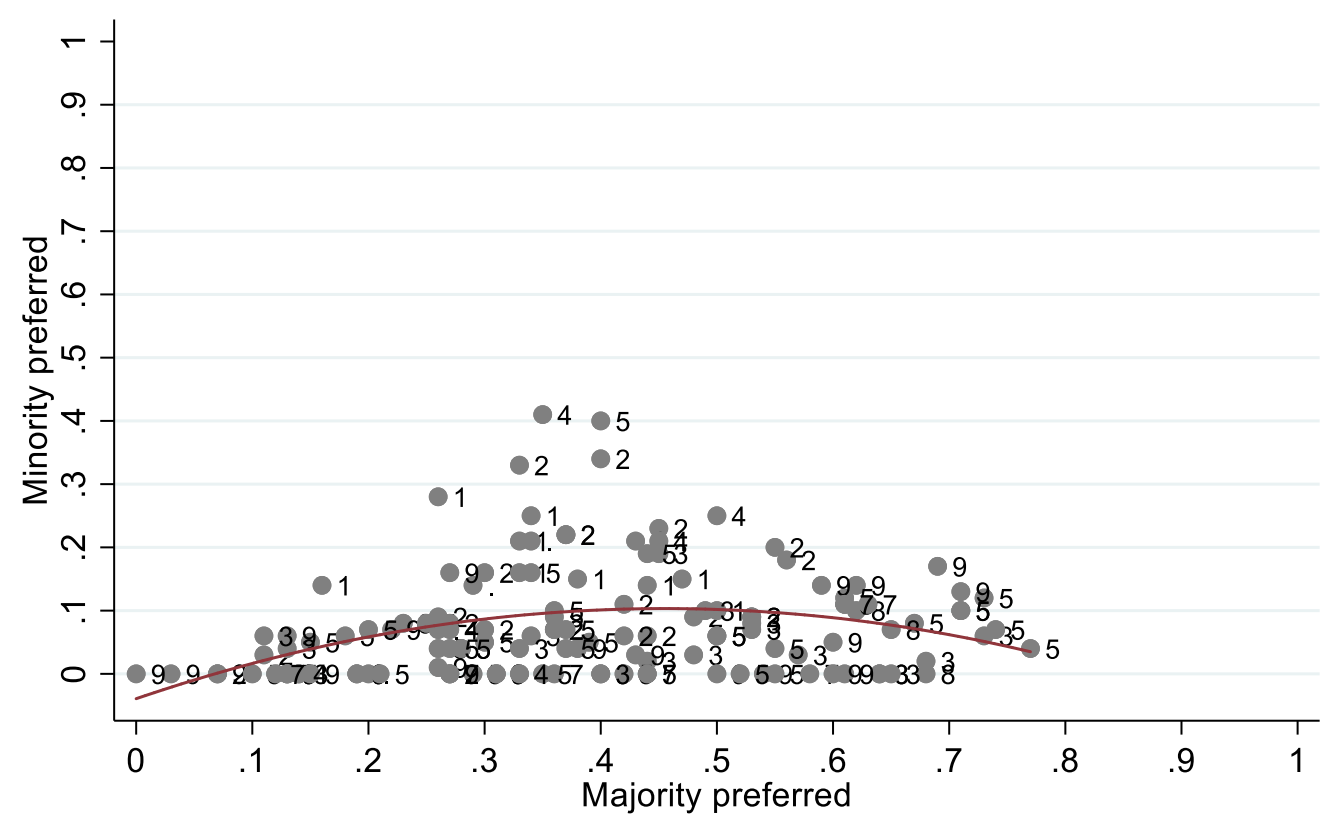

Label: ISCO (1-digit)

Quadratic fit, $N=139$ 